\title{
Fixation of rotationally unstable extracapsular proximal femoral fractures
}

\author{
Elsayed Ibraheem Elsayed Massoud, M.D.
}

Department of Orthopaedic, Sohag Teaching Hospital, General Organization for Teaching Hospitals and Institutes, Sohag - Egypt

\begin{abstract}
BACKGROUND: It was thought that the AO types AI.2 and AI.3 fractures are rotationally stable; however, it revealed instability when fixed using the dynamic hip screw. Therefore, we hypothesized that these fractures should be treated as rotationally unstable.

METHODS: A series of 83 fractures of the AO types AI,A2, and B2.I were treated using dynamic hip screw with derotation screw (DHS/DRS) composite and then prospectively followed for 24 months. Adequacy of reduction and fixation were immediately assessed after surgery, and fracture collapse was assessed at six months or when fractures healed. To investigate the feasibility of our hypothesis, fractures were classified into two groups: I) the inevitably unstable group (IUG) included the AO types AI.I,A2.I, A2.2, A2.3, and B2.I fractures and 2) the potentially unstable group (PUG) included the AO types AI.2 and AI.3 fractures. The results were statistically analyzed.
\end{abstract}

RESULTS: Adequate reduction was achieved in 77 and adequate fixation in $7 \mathrm{I}$ fractures. All fractures healed in a mean time of 13.5 weeks, and the amount of the fracture collapse averaged $5.8 \mathrm{~mm}$. Equalization of the lower limbs was achieved in 66 patients, and hip motion range equalized the healthy contralateral in 80 patients. Re-operation was performed in one case with AO type AI.2. Comparison of IUG and PUG using the outcomes revealed insignificant differences.

CONCLUSION: Using the DHS/DRS composite, anatomical features of the proximal femoral end were restored and maintained during the follow-up period. Insignificant differences between outcomes of IGU and PGU render the addition of the AO types AI.2 and AI.3 to the rotationally unstable fractures reasonable.

Keywords: Basicervical fracture; derotation screw; DHS/DRS composite; dynamic hip screw; proximal femoral fractures; rotational instability; trochanteric fractures.

\section{INTRODUCTION}

Extracapsular proximal femoral fractures occur distal to the hip joint capsule. ${ }^{[I]}$ These fractures are subdivided into subtrochanteric, intertrochanteric, and basicervical fractures, with each type having different management options and prognostic implications. ${ }^{[2,3]}$ Generally, successful management necessitates differentiation between stable and unstable fractures. However, the current classification systems have restricted the instability only at the vertical plane. ${ }^{[2,4]}$ Recently, rotational instability has resurfaced as a potential hazard and this could threaten even a stable fracture. This has been predicted increasingly when a single cephalic screw was used for fixation, of a fracture in which the proximal fragment was separated from the trochanters through a high-angle fracture line..$^{[3,5-7]}$

For achieving a stable fixation, many modifications have been introduced on the already existing implants. Although the dynamic hip screw (DHS) has been considered as the standard

Cite this article as: Massoud EIE. Fixation of rotationally unstable extracapsular proximal femoral fractures. Ulus Travma Acil Cerrahi Derg 2018;24:168-174

Address for correspondence: Elsayed Ibraheem Elsayed Massoud, M.D.

Nile St Sohag 00 Sohag, Egypt

Tel: +2 0934790632 E-mail: elsayedmassoud@hotmail.com

Ulus Travma Acil Cerrahi Derg 2018;24(2):168-174 DOI: 10.5505/tjtes.2017.4704I Submitted: 23.09.2017 Accepted: 10.11.2017 Online: 15.02.2018

Copyright 2018 Turkish Association of Trauma and Emergency Surgery 
implant for the fixation of intertrochanteric fractures, ${ }^{[1,2]}$ it failed in the fixation of unstable fractures. Therefore, some authors have augmented DHS with resorbable cement, and others preferred the peripheral femoral nails (PFN).[2,8] However, for the reported complications with PFN, ${ }^{[9,10]}$ the proximal femoral nail antirotation was designed. ${ }^{[1]}$ However, the anti-rotational device was related to early complications arising from its position, and later, like as a " $Z$ effect." ${ }^{5,12]}$ $Z$-effect, defined as a complication results from the collapse of the proximal fracture fragment that lead to a medial migration of the superior lag screw and lateral migration of the inferior lag screw. ${ }^{[5]}$

In a previous study, ${ }^{\left[{ }^{[3]}\right.}$ we have achieved successful results using a composite of DHS with derotation screw (DHS/DRS composite) for the fixation of a group of fractures, which were assigned as rotationally unstable. The AO types AI.2 and Al.3 fractures were not included in the previous study because they were thought to be rotationally stable..$^{[4]}$ However, when these fractures types were fixed with the DHS alone, have reported complications likely related to the rotational instability. Therefore, we hypothesized that these fractures do not differ from the rotationally unstable fractures because it carries multiple criteria of the rotational instability.

The aims of this study were two-fold: firstly, to present the results of using the DHS/DRS composite in the fixation of a prospective series of 83 rotationally unstable fractures; secondly, to investigate the feasibility of our null hypothesis using the outcomes.

\section{METHODS}

Between August 2009 and August 2013, we conducted a prospective study that included 83 patients who agreed to participate. The Local Ethics Committee approved the study. The primary assessment included interviews with the patients regarding their walking ability that was classified into two categories: I) ability to walk independently without any aid and 2) ability to walk independently with one cane. A radiologist and a senior orthopedic surgeon identified the fractures pattern using $X$-ray, and the fractures were then classified according to the $\mathrm{AO}$ classification system. ${ }^{\left[{ }^{13]}\right.}$

We included who were walks and who were using one walking stick, present with extracapsular proximal femoral fractures that have met the criteria of the rotational instability. The included fractures were the AO types AI.I, 2, 3, A2.I, 2,3 , and B2.I fractures. The criteria of rotational instability are as follows: the head-neck fragment does not remain connected to the trochanters, is separated by a high-angle fracture line, and its inferior cortical extension is not long enough to hinder its rotation. ${ }^{[3,5]}$ For this study, the AO types AI.2 and AI. 3 fractures were exceptionally included because they lacked one criterion of the rotational instability. The headneck fragment has a fraction of the greater trochanter in the type AI.2, whereas it has a long inferior cortical extension in the type AI.3. Consequently, fractures were classified into two groups: I) the inevitably unstable group (IUG) included 60 fractures of the AO types AI.I, A2.I, 2, 3, and B2.I fractures and 2) the potentially unstable group (PUG) included 23 fractures of the AO types AI.2 and AI.3 fractures. To explore the feasibility of gathering both groups within a group for the rotationally unstable fractures, results were statistically analyzed. We excluded patients with intracapsular fractures, the $A O$ type $A 3$, pathological fractures, and hips with advanced arthritis.

\section{Operative Technique}

The fracture was exposed by a straight lateral incision. Using the angle guide, a pin was inserted into the subchondral level of the femoral head. A K-wire was placed parallel and proxi$\mathrm{mal}$ to the guide pin at a distance of approximately $13 \mathrm{~mm}$, so that spinning of the head-neck fragment during the reaming or screw insertion can be controlled. After insertion of the DHS components, a partially threaded cannulated cancellous screw of suitable length, with a washer, was inserted onto the $\mathrm{K}$-wire to act as a DRS. A suction drainage system was inserted submuscular, and the wound was closed.

\section{Follow-Up}

Postoperative management was determined based on the quality of reduction obtained. Patients with good reduction were allowed to walk using crutches until a good callus was observed, and then progressive weight bearing was started. However, if the reduction was considered as not good, partial weight bearing was allowed only when the callus bridged the fracture line. Patients received antithrombotics (low molecular weight heparins) and prophylactic doses of antibiotics (third generation cephalosporin). Follow-up examinations were carried out every other week for 16 weeks and then every other month. After the first year, patients were evaluated twice per year, and outcomes were assessed at 24 months postoperatively.

\section{Radiological Assessment}

Adequacy of reduction was immediately assessed after surgery and classified as adequate when the neck-shaft angle $<10^{\circ}$ varus or $<15^{\circ}$ valgus compared with the contralateral hip and displacement between the fragments was $<3 \mathrm{~mm}$ in any of the AP and lateral radiographs. ${ }^{[3]}$ Adequacy of fixation was rated by assessing the placement of the lag screw within the femoral head using two independent classifications. First, according to the nine zones classification of the femoral head, ${ }^{[14]}$ adequate grade was given when the screw was placed inferior/central, central/central, or inferior/ posterior in AP/ lateral views. However, superior and/or anterior placement was considered inadequate. Second, the tip apex distance (TAD) of $<20 \mathrm{~mm}$ in both AP and lateral views was considered adequate. ${ }^{[3]}$ The parallelism between the lag screw and DRS was deemed adequate and was used as an indicator 
of the preservation of reduction in subsequent radiographs. Convergence of the DHS/DRS composite is deemed inadequate. ${ }^{[3]}$ Time to union was calculated from the surgery date to the healing date, which was indicated when the trabeculae extended across the fracture line. Non-union was defined as absence of the bridging bone at the fracture line by follow-up at six months, including progressive displacements. ${ }^{[3]}$ Fracture collapse was equivalent to the sliding distance, which was defined as the length of protrusion of the lag screw from the lateral edge of the barrel when measured at the 6th month postoperatively or when the fracture healed. According to Mattsson et al., ${ }^{[15]}$ the sliding distance was classified into excellent $(<6 \mathrm{~mm})$, good $(<15 \mathrm{~mm})$, and poor (at $16 \mathrm{~mm}$ or more).

\section{Clinical Assessment}

Motion of the hip joint was measured using a goniometer and compared with the healthy contralateral. The lengths of both the lower extremities were measured and compared. Functional outcomes were evaluated according to the modified criteria of Kyle et al. ${ }^{[14]}$ The excellent result was given for patients who had a normal range of motion, who had minimum limp without pain, and who rarely used a cane (provided that they did not use a cane in the pre-fracture period). The good result was given for patients who had a normal range of motion, but had a noticeable limp with occasional mild pain, and who used a cane (provided that they did not use a cane in the pre-fracture period). The fair result was given for patients who had a limited range of motion, a noticeable limp, moderate pain and who used two canes or a walker. The poor result was given for patients who had pain on any motion and who were in a wheelchair or who were non-ambulatory.

\section{Statistical Analysis}

The data are categorical and included two and three categories. First, the variables with two-category data were ad- equacy of reduction, adequacy of fixation, and legs' lengths. Chi-square Calculator for $2 \times 2$ Contingency Table test was used for the analysis of the legs' lengths variable. Fisher Exact Test Calculator for $2 \times 2$ Contingency Table test was used for the analysis of the adequacy of reduction and adequacy of fixation (this test was employed instead of Pearson's chi-square test when sample sizes are $<5$ ). Second, Chi-square Calculator for $5 \times 5$ (or less) Contingency Table test was used for the analysis of the variables with three-category data, which were sliding distance and functional outcomes. Significant difference was set at $p<0.05$. Statistical analysis was performed using the online calculator at the website http://www.socscistatistics.com/tests/Default.aspx.

\section{RESULTS}

The study included 83 patients with 83 fractures; their mean age at surgery was 61.3 (range: $38-85$ years). The preoperative details are listed in Table $\mathbf{I}$.

\section{Radiographic Results}

The reduction was rated as adequate in 77 and inadequate in six fractures. The inadequacy of reduction was related to that the neck-shaft angle exceeded the contralateral by $<15^{\circ}$ in four fractures and lowered by $>10^{\circ}$ in one fracture, and the displacement between the fragments was $>3 \mathrm{~mm}$ in six fractures. Criteria for the inadequacy of reduction were noticed together in five fractures (Table 2). Measurements of the neck-shaft angles remained preserved to the final assessment, except in one case that was re-operated upon (Fig. I). Fixation was considered adequate in $7 \mathrm{I}$ fractures and inadequate in 12 fractures, because TAD exceeded $20 \mathrm{~mm}$ in 12 fractures and the lag screw was placed superior in II femoral heads. Criteria of the inadequacy of fixation were noticed together in II fractures (Table 2). All fractures healed within a mean period of 13.5 weeks (range: 10-30 weeks). Fracture

Table I. Preoperative details for patients with rotationally unstable proximal femoral fractures

\begin{tabular}{|c|c|c|c|c|c|c|c|c|c|}
\hline \multirow[t]{2}{*}{ Types of fractures } & \multirow{2}{*}{$\begin{array}{l}\text { Fractures } \\
\text { numbers }\end{array}$} & \multicolumn{2}{|c|}{ Age (years) } & \multicolumn{2}{|c|}{ Gender } & \multicolumn{2}{|c|}{ Side } & \multicolumn{2}{|c|}{ Walking aid } \\
\hline & & Average & Range & Male & Female & Right & Left & No & Yeas \\
\hline Inevitably unstable & 60 & 60.5 & $38-85$ & 27 & 33 & 37 & 23 & 50 & 10 \\
\hline AO type AI.I & 8 & 66.3 & $50-85$ & 5 & 3 & 5 & 3 & 5 & 3 \\
\hline AO type $A 2 . I$ & 12 & 56.6 & $38-70$ & 7 & 5 & 7 & 5 & II & I \\
\hline AO type $A 2.2$ & 17 & 59.4 & $44-78$ & 5 & 12 & 13 & 4 & 15 & 2 \\
\hline AO type $\mathrm{A} 2.3$ & 14 & 60.8 & $46-79$ & 4 & 10 & 5 & 9 & 12 & 2 \\
\hline AO type B2.I & 9 & 61.8 & $42-80$ & 6 & 3 & 7 & 2 & 7 & 2 \\
\hline Potentially unstable & 23 & 63.5 & $43-80$ & 10 & 13 & 13 & 10 & 20 & 3 \\
\hline AO type AI.2 & 18 & 66 & $55-80$ & 7 & 11 & 11 & 7 & 15 & 3 \\
\hline AO type AI.3 & 5 & 55 & $43-66$ & 3 & 2 & 2 & 3 & 5 & 0 \\
\hline Total & 83 & 61.3 & $38-85$ & 37 & 46 & 50 & 33 & 70 & 13 \\
\hline
\end{tabular}


Table 2. Adequacy of the reduction and fixation in immediate postoperative radiographs

\begin{tabular}{|c|c|c|c|c|c|c|c|c|c|c|c|c|}
\hline \multirow[t]{3}{*}{ Types of fractures } & \multicolumn{4}{|c|}{ Adequacy of reduction } & \multicolumn{8}{|c|}{ Adequacy of fixation } \\
\hline & \multicolumn{2}{|c|}{$\begin{array}{l}\text { FNS angle } \\
\text { (compared to } \\
\text { other side) }\end{array}$} & \multicolumn{2}{|c|}{$\begin{array}{l}\text { Fragmentary } \\
\text { displacement }\end{array}$} & \multicolumn{2}{|c|}{$\begin{array}{l}\text { Tip apex } \\
\text { distance }\end{array}$} & \multicolumn{4}{|c|}{$\begin{array}{l}\text { Lag screw } \\
\text { placement }\end{array}$} & \multicolumn{2}{|c|}{$\begin{array}{c}\text { Derotation screw } \\
\text { parallelism }\end{array}$} \\
\hline & Equal & Unequal & $<3 \mathrm{~mm}$ & $>3 \mathrm{~mm}$ & $<20 \mathrm{~mm}$ & $>20 \mathrm{~mm}$ & $\mathrm{C} / \mathrm{C}$ & I/C & $\mathbf{I} / \mathbf{P}$ & S/C & Parallel & Converge \\
\hline Inevitably unstable & 57 & 3 & 55 & 4 & 53 & 7 & 3 & 12 & 36 & 9 & 54 & 6 \\
\hline AO type AI.I & 8 & 0 & 8 & 0 & 7 & 1 & 1 & I & 4 & 2 & 7 & 1 \\
\hline AO type $A 2.1$ & 12 & 0 & 12 & 0 & II & 1 & 0 & 4 & 7 & I & II & 1 \\
\hline AO type $\mathrm{A} 2.2$ & 16 & I valgus & 15 & 1 & 15 & 2 & 0 & 3 & II & 3 & 15 & 2 \\
\hline AO type $\mathrm{A} 2.3$ & 12 & 2 valgus & 12 & 2 & 12 & 2 & 1 & 2 & 9 & 2 & 13 & 1 \\
\hline AO type B2.I & 9 & 0 & 8 & I & 8 & I & 1 & 2 & 5 & I & 8 & 1 \\
\hline Potentially unstable & 21 & 2 & 21 & 2 & 18 & 5 & 0 & 8 & 13 & 2 & 19 & 4 \\
\hline AO type Al. 2 & 17 & I varus & 17 & 1 & 15 & 3 & 0 & 7 & 10 & 1 & 15 & 3 \\
\hline AO type AI.3 & 4 & I valgus & 4 & I & 3 & 2 & 0 & I & 3 & I & 4 & 1 \\
\hline
\end{tabular}

FNS angle: Femoral neck-shaft angle; C/C: Central/central; I/C=Inferior/central; I/P = Inferior/posterior; S/C: Superior/central.

collapse was estimated according to the sliding distance that averaged $5.8 \mathrm{~mm}$ (range: $2-20 \mathrm{~mm}$ ). The rating was excellent in 59, good in 22, and poor in two fractures (Table 3).

\section{Clinical Results}

At the final visit, the numbers of patients who used one cane increased from 13 to 18 , and three of them use two walking aids instead of one. Equalization of both lower limbs was achieved in 66 patients; however, leg shortening that averaged $4.6 \mathrm{~mm}$ (range: $0-30 \mathrm{~mm}$ )] was reported in 17 patients (Table 3). Hip motion range equalized the healthy contralateral in 80 patients, but three patients exhibited a limitation of motion.
According to the modified criteria of Kyle et al., ${ }^{[14]} 69$ patients obtained excellent, II achieved good, and three achieved fair results (Table 3 ).

Comparison of IUG and PUG using outcomes: In IUG, the reduction was rated as adequate in 56/60 and inadequate in 4/60 fractures, whereas in PUG, it was adequate in 21/23 and inadequate in $2 / 23$ fractures. The difference between both groups was statistically insignificant $(p=0.67)$. The fixation in IUG was rated as adequate in 52/60 and inadequate in 8/60 fractures, whereas in PUG, it was adequate in 19/23 and inadequate in $4 / 23$ fractures. The difference was statistically insignificant
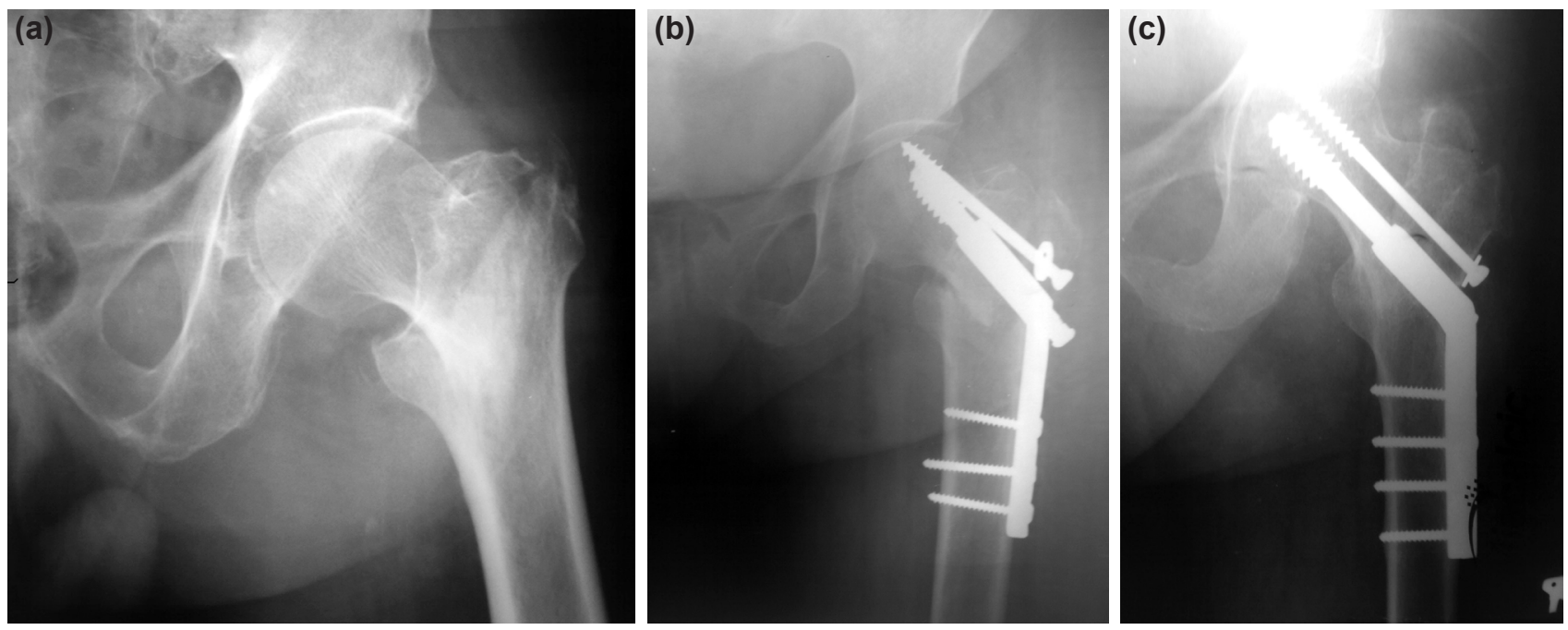

Figure 1. (a) Preoperative anteroposterior radiograph for the right hip joint of a 69-year-old female shows the AO type $A 1.2$ trochanteric fracture. (b) AP radiograph at two weeks after surgery shows varus drift and excessive displacement of the head-neck fragment due to inadequate reduction and fixation. Note the placement of the DHS/DRS composite superior in the femoral head and convergence of DRS. (c) AP radiograph at six months after re-operation shows fracture healing, preserved neck-shaft angle, maintained parallelism between the cephalic screws of the DHS/DRS composite, and excellent sliding of the lag screw. 
Table 3. Outcomes of limb functions for patients treated for rotationally unstable fractures

\begin{tabular}{|c|c|c|c|c|c|c|c|c|c|}
\hline \multirow[t]{2}{*}{ Types of fractures } & \multicolumn{3}{|c|}{ Sliding distance } & \multicolumn{2}{|c|}{ Legs length } & \multicolumn{4}{|c|}{ Functional outcomes } \\
\hline & Excellent & Good & Poor & Equal & Unequal & Excellent & Good & Fair & Poor \\
\hline Inevitably unstable & 43 & 16 & I & 48 & 12 & 51 & 7 & 2 & 0 \\
\hline AO type AI.I & 6 & 2 & 0 & 6 & 2 & 6 & 2 & 0 & 0 \\
\hline AO type $\mathrm{A} 2 . \mathrm{I}$ & 10 & 2 & 0 & 10 & 2 & 12 & 0 & 0 & 0 \\
\hline AO type $\mathrm{A} 2.2$ & 12 & 5 & 0 & 15 & 2 & 15 & I & 1 & 0 \\
\hline AO type $\mathrm{A} 2.3$ & 9 & 4 & I & II & 3 & II & 2 & 1 & 0 \\
\hline AO type $B 2.1$ & 6 & 3 & 0 & 6 & 3 & 7 & 2 & 0 & 0 \\
\hline Potentially unstable & 16 & 6 & I & 18 & 5 & 18 & 4 & I & 0 \\
\hline AO type AI.2 & 14 & 3 & I & 14 & 4 & 14 & 3 & 1 & 0 \\
\hline AO type AI.3 & 2 & 3 & 0 & 4 & I & 4 & I & 0 & 0 \\
\hline
\end{tabular}

$(p=0.73)$. In IUG, the sliding distance was rated as excellent in $43 / 60$, good in 16/60, and poor in 1/60 fractures. In PUG, the sliding distance was rated as excellent in $16 / 23$, good in $6 / 23$, and poor in $1 / 23$ fractures. The difference was statistically insignificant $(p=0.77)$. Equalization of legs' lengths in IUG was achieved in 48/60 patients; however, $12 / 60$ patients reported discrepancy, whereas in PUG, the equalization was achieved in $18 / 23$ and discrepancy was reported in 5/23 patients. The difference was statistically insignificant $(p=0.86)$. The functional outcome in IUG was rated as excellent in $51 / 60$, good in $7 / 60$, and fair in 2/60 patients. In PUG, it was rated as excellent in $18 / 23$, good in $4 / 23$, and fair in $1 / 23$ patients. The difference was statistically insignificant $(p=0.76)$.

\section{Complications}

There were no general complications or deaths during the follow-up period. However, a re-operation was performed in one case with AO type Al.2 that showed excessive displacement of the proximal fragment in the postoperative radiograph due to inadequate reduction and fixation (Fig. I). Superficial infection was noticed in four patients at the postoperative 3rd week. Infection was controlled with parenteral antibiotic and daily wound dressing. According to Brooker et al. ${ }^{[16]}$ classification, heterotopic ossification classes II and III was observed in eight patients, 3 of whom reported limitation of hip motion at the final visit.

\section{DISCUSSION}

In terms of rotational instability, extracapsular proximal femoral fractures are not alike. When constructed using solitary cephalic screw implant, most of them demonstrated instability. Identification of the rotationally unstable fractures offers insight for selecting the suitable fixation device. A simple modification of DHS through an addition of DRS will offer a compatible solution.

In a previous study, we identified a group of rotationally un- stable fractures, which reported satisfactory results when fixed using the DHS/DRS composite. ${ }^{[3]}$ These fractures are the AO types AI.I, A2.I, 2, 3, and B2.I. In these fractures, the commonalities are that the head-neck fragment does not remain connected to the trochanters, is separated by a highangle fracture line, and has no distal extension that can hinder the rotation. ${ }^{[3,5]}$ The $A O$ types AI.2 and AI.3 fractures that were not included in the previous study when were fixed using DHS alone exhibited rotation of the proximal fragment around the lag screw during its insertion as well as loss of reduction postoperatively. It is worth noting that the headneck fragment in the AO types Al.2 and Al.3 fractures is separated by a high-angle fracture line, which can generate a shear force as well as rotational instability. ${ }^{[6,7]}$

Although the AO types AI.I, 2, and 3 fractures are equivalent to the stable fractures in Jensen classification, ${ }^{[4]}$ Jensen et al., ${ }^{[17]}$ in another study, when used an implant with a single cephalic screw, reported varus displacement in II of the stable fractures group. ${ }^{\left[{ }^{[7]}\right.}$ Jensen has related the instability to the separation of the head-neck fragment from the trochanters; however, he did not explain how it occurred. ${ }^{[4]}$ The hip joint is a ball-and-socket joint; therefore, its motions are completely rotational. ${ }^{[18]}$ Lenich et al., ${ }^{[19]}$ described that the rotation will not occur when the single cephalic implant is placed in the theoretical center of the femoral head, which its anatomy renders this is impossible. The authors, therefore, believed that implantation of a single cephalic screw leads to cutout. ${ }^{[19]}$

Immediate postoperative radiography measures adequacy of reduction and fixation (Table 2 ). This suggested that the differences in outcomes were because of the inefficiency of the DHS/DRS composite to control rotation. In this study, changes in the neck-shaft angle, re-displacement, excessive sliding, and limb shortening are primarily correlated to the inadequacy of reduction and/or fixation, rather than the implanted composite, so why the adequately reduced and fixed fractures achieved satisfactory outcomes (Tables 2, 3). 
Shortening of the femoral neck and/or limb can be a result of the bone collapse, varus drift, or distal migration of the proximal fragment. ${ }^{[8,15,19]}$ Pajarinen et al..$^{[8]}$ have reported fracture collapse of $6.1 \mathrm{~mm}$ (range 0-30 mm) and a mean shortening of the limb of $4.7 \mathrm{~mm}$ (range $0-25 \mathrm{~mm}$ ) in a group of patients $(n=4 I)$ treated with DHS. Mattsson et al. ${ }^{[15]}$ have compared the outcomes of using DHS without and with resorbable cement augmentation in the fixation of trochanteric fractures. They reported mean sliding distances of $15.9 \mathrm{~mm}$ with DHS alone and $13.5 \mathrm{~mm}$ when augmented. Moreover, they pointed out that a sliding distance of $<6.7 \mathrm{~mm}$ did not affect limb mobility; therefore, they have correlated reduction of limb mobility with the sliding distance. ${ }^{[15]}$ In the present study, a mean fracture collapse of $5.8 \mathrm{~mm}$ (range: $2-20 \mathrm{~mm}$ ) and a mean limb shortening of $4.6 \mathrm{~mm}$ (range: $0-30 \mathrm{~mm}$ ) were observed. Noteworthy, fracture collapse and limb shortening were consistently noticed together (Table 2). It has been reported that the high-angle fracture line contributes to limb shortening because it can displace the head-neck fragment distally. ${ }^{[3,7]}$ Accordingly, we appreciate the role of DRS, which is fastened as a rafter between the lateral femoral cortex and subchondral bone of the femoral head, in control of the shear force.

The present study has resurfaced the phenomenon of a rotational instability to the light and presents it as a potential hazard could be avoided as well identified a group of fractures has a susceptibility for rotation, albeit clinically. The hypothesis and outcomes have support from published biomechanical and clinical studies. However, the limitations of this study lie in being a case series study including a small number of patients and lacking biomechanical evaluation of its hypothesis. Therefore, a power, multicenter, and randomized control study is required to demonstrate the merits of the present technique compared with other techniques, coinciding with the biomechanical studies to provide more evidence for the assumptions.

\section{Conclusion}

The DHS/DRS composite has restored and maintained the anatomical features of the proximal femoral end for the treated fractures as well as restored the limbs' functions during the follow-up period. The similarity in the anatomical features of the head-neck fragment and the insignificant differences between the outcomes of the inevitable and potential rotationally unstable groups renders addition of the $A O$ types $A I .2$ and $A I .3$ fractures to the rotationally unstable fractures reasonable.

\section{Acknowledgement}

I'm really grateful to pharmacist Abdulsamad Mahran (Sohag Teaching Hospital) he exerted an effort and spent a time in making the statistical analysis of the present study.

Conflict of interest: None declared.

\section{REFERENCES}

1. Oliver D, Griffiths R, Roche J, Sahota O. Hip fracture. BMJ Clin Evid 2007. pii: 1110.

2. Mittal R, Banerjee S. Proximal femoral fractures: Principles of management and review of literature. J Clin Orthop Trauma 2012;3:15-23.

3. Massoud EI. Fixation of basicervical and related fractures. Int Orthop 2010;34:577-82. [CrossRef]

4. Jensen JS. Classification of trochanteric fractures. Acta Orthop Scand 1980;51:803-10. [CrossRef]

5. Aguado-Maestro I, Escudero-Marcos R, García-García JM, Alonso-García N, Pérez-Bermejo D D, Aguado-Hernández HJ, et al. Results and complications of pertrochanteric hip fractures using an intramedullary nail with a helical blade (proximal femoral nail antirotation) in $200 \mathrm{pa}-$ tients. Rev Esp Cir Ortop Traumatol 2013;57:201-7. [CrossRef]

6. Deneka DA, Simonian PT, Stankewich CJ, Eckert D, Chapman JR, Tencer AF. Biomechanical comparison of internal fixation techniques for the treatment of unstable basicervical femoral neck fractures. J Orthop Trauma 1997;11:337-43. [CrossRef]

7. Baitner AC, Maurer SG, Hickey DG, Jazrawi LM, Kummer FJ, Jamal J, et al. Vertical shear fractures of the femoral neck. A biomechanical study. Clin Orthop Relat Res 1999:300-5. [CrossRef]

8. Pajarinen J, Lindahl J, Michelsson O, Savolainen V, Hirvensalo E. Pertrochanteric femoral fractures treated with a dynamic hip screw or a proximal femoral nail. A randomised study comparing post-operative rehabilitation. J Bone Joint Surg Br 2005;87:76-81. [CrossRef]

9. Foulongne E, Gilleron M, Roussignol X, Lenoble E, Dujardin F. Miniinvasive nail versus DHS to fix pertrochanteric fractures: a case-control study. Orthop Traumatol Surg Res 2009;95:592-8. [CrossRef]

10. Watson ST, Schaller TM, Tanner SL, Adams JD, Jeray KJ. Outcomes of Low-Energy Basicervical Proximal Femoral Fractures Treated with Cephalomedullary Fixation. J Bone Joint Surg Am 2016;98:1097-102.

11. Xu YZ, Geng DC, Mao HQ, Zhu XS, Yang HL. A comparison of the proximal femoral nail antirotation device and dynamic hip screw in the treatment of unstable pertrochanteric fracture. J Int Med Res 2010;38:1266-75. [CrossRef]

12. Takano MI, de Moraes RC, de Almeida LG, Queiroz RD. Analysis of using antirotational device on cephalomedullary nail for proximal femoral fractures. Rev Bras Ortop 2014;49:17-24. [CrossRef]

13. Müller ME, Allgöwer M, Schneider R, Willenegger $H$, editors. Proximal femur. In: Manual of internal fixation: techniques recommended by the AO-ASIF Group. 3rd ed. Berlin: Springer; 1992. p. 522-30. [CrossRef]

14. Kyle RF, Gustilo RB, Premer RF. Analysis of six hundred and twenty-two intertrochanteric hip fractures. J Bone Joint Surg Am 1979;61:216-21.

15. Mattsson P, Alberts A, Dahlberg G, Sohlman M, Hyldahl HC, Larsson S. Resorbable cement for the augmentation of internally-fixed unstable trochanteric fractures. A prospective, randomised multicentre study. J Bone Joint Surg Br 2005;87:1203-9. [CrossRef]

16. Brooker AF, Bowerman JW, Robinson RA, Riley LH Jr. Ectopic ossification following total hip replacement. Incidence and a method of classification. J Bone Joint Surg Am 1973;55:1629-32. [CrossRef]

17. Jensen JS, Michaelsen M. Trochanteric femoral fractures treated with McLaughlin osteosynthesis. Acta Orthop Scand 1975;46:795-803.

18. Baerlocher P, Boulic R. Parametrization and range of motion of the balland socket joint. Proceedings of AVATARS'2000 Conference. Lausanne: 2000; p. 180-90.

19. Lenich A, Bachmeier S, Prantl L, Nerlich M, Hammer J, Mayr E, et al. Is the rotation of the femoral head a potential initiation for cutting out? A theoretical and experimental approach. BMC Musculoskelet Disord 2011;12:79. [CrossRef] 
ORİINAL ÇALIŞMA - ÖZET

\section{Rotasyonel instabil ekstrakapsüler proksimal femur kırıkları}

\section{Dr. Elsayed Ibraheem Elsayed Massoud}

Sohag Eğitim Hastanesi, Ortopedi Bölümü, Eğitim Hastaneleri ve Kurumları Organizasyonu, Sohag-Mısır

AMAÇ: AO tipleri AI.2 ve Al.3 kırıklarının rotasyonel instabil olduğu düşünülmesine rağmen, dinamik kalça vidası ile tespitten sonra stabil olmadıkları ortaya çıkmıştır. Bu nedenle bu kırıkların rotasyonel instabil kırıklar gibi tedavi edilmesi gerektiğini varsaymaktayız.

GEREÇ VE YÖNTEM: AO tip AI, A2 and B2.I kırıkları olan 83 kırıklık bir seri DKV/DRV ile tedavi edildikten sonra 24 ay izlendi. Ameliyattan hemen sonra, redüksiyonun ve fiksasyonun yeterliliği, altıncı aylarda veya kırıklar iyileştiğinde ise kırık bölgesindeki çökme değerlendirildi. Varsayımımızın uygulanabilirliğini araştırmak için kırıklar iki gruba ayrıldı: Kaçınılmaz olarak instabil kırık grubu (KIKG) AO tip AI. I, A2. I,2,3 ve B2. I kırıkları, potansiyel olarak instabil kırık grubu (PIKG) AO tip AI.2 ve AI.3 kırıkları içermekteydi. Sonuçlar istatistiksel açıdan analiz edildi.

BULGULAR: Yetmiş yedi kırıkta yeterli redüksiyon ve 7 I'inde yeterli fiksasyon sağlandı. Kırıkların tümü ortalama I3.5 haftada iyileşti ve kırık bölgesinde ortalama 5.8 mm'lik çökme (kolaps) oluştu. Altmış altı hastada her iki alt ekstremite eşitlendi, 80 hastada kalça hareket erimi diğer sağlam kalçanın hareket erimine kavuştu. Bir AO tip AI.2’li hasta yeniden ameliyata alındı. Sonuçların karşılaştırılmasına göre KIKG ile PIKG arasında önemsiz farklılıklar vardı.

TARTIŞMA: DKV/DRS ile femurun proksimal ucunun anatomik özellikleri orijinal haline getirilmiş ve takip dönemi sırasında bu durum korunmuştur. KIKG ile PIKG sonuçları arasında önemsiz farklılıklar, rotasyonel instabil kırıklara AO tip AI.2 ve AI.3 kırıkların da ilavesi akla yakındır.

Anahtar sözcükler: Bazoservikal kırık; derotasyon vidası; DHS/DRS kompozit; dinamik kalça vidası; proksimal femor kırıkları; rotasyonel instabilite; trokanterik kırıklar.

Ulus Travma Acil Cerrahi Derg 2018;24(2):I68-I74 doi: 10.5505/tjtes.2017.4704I 